This document is confidential and is proprietary to the American Chemical Society and its authors. Do not copy or disclose without written permission. If you have received this item in error, notify the sender and delete all copies.

\title{
A Conventional Multiplex PCR assay for the detection of toxic Gemfish species (Ruvettus pretiosus and Lepidocybium flavobrunneum): a simple method to combat health frauds.
}

\begin{tabular}{|r|l|}
\hline Journal: & Journal of Agricultural and Food Chemistry \\
\hline Manuscript ID & jf-2015-04899x.R1 \\
\hline Manuscript Type: & Article \\
\hline Date Submitted by the Author: & $\mathrm{n} / \mathrm{a}$ \\
\hline Complete List of Authors: & $\begin{array}{l}\text { Giusti, Alice; University of Pisa, Department of Veterinary Sciences-FishLab } \\
\text { Castigliego, Lorenzo; Department of Veterinary Sciences, University of } \\
\text { Pisa, } \\
\text { Rubino, Rossella; University of Pisa, Department of Veterinary Sceinces } \\
\text { Gianfalodni, Daniela; University of Pisa, Department of Veterinary Sceinces } \\
\text { Guidi, Alessandra; University of Pisa, Department of Veterinary Sceinces } \\
\text { Armani, Andrea; University of Pisa, Department of Veterinary Sceinces }\end{array}$ \\
\hline
\end{tabular}

SCHOLARONE

Manuscripts 
A Conventional Multiplex PCR assay for the detection of toxic gemfish species (Ruvettus pretiosus and Lepidocybium flavobrunneum): a simple method to combat health frauds.

3

4 Alice Giusti, Lorenzo Castigliego, Rossella Rubino, Daniela Gianfaldoni, Alessandra Guidi, $5 \quad$ Andrea Armani * Pisa (Italy).

8

$22 *$ corresponding author:

23 Postal address: FishLab, Department of Veterinary Sciences, University of Pisa, Viale delle 24 Piagge 2, 56124, Pisa (Italy)

25 Tel: +390502210207; Fax: +390502210213

26 Email: andrea.armani@unipi.it 

9

\section{Abstract}

The meat of Ruvettus pretiosus and Lepidocybium flavobrunneum (gemfishes) contains high amounts of indigestible wax esters that provoke gastrointestinal disorders. Although some countries banned the sale of these species, mislabelling cases have been reported in sushi catering. In this work, we developed a simple Conventional Multiplex PCR, which discriminates the two toxic gemfishes from other potentially replaced species, such as tunas, cod and sablefish. A common degenerate forward primer and three specie-specific reverse primers were designed to amplify Cytochrome oxidase subunit I (COI) gene regions of different lengths $(479,403$ and $291 \mathrm{bp})$ of gemfishes, tunas and sablefish, respectively. A primer pair was designed to amplify a fragment (193 bp) of the $c y t b$ gene of cod species. Furthermore, a primer pair targeting the $16 S$ rRNA gene was intended as common positive control (115 bp). The method developed in this study, by producing the expected amplicon for all the DNA samples tested (reference and commercial), provide a rapid and reliable response in identifying the two toxic species and combat health frauds.

\section{Keywords}

Gempylidae, health frauds, mislabeling, multiplex PCR, mitochondrial genes

(1)

3

4

5

6

\section{7}

\section{8} 50 51 52 


\section{Introduction}

Oilfish (Ruvettus pretiosus) and escolar (Lepidocybium flavobrunneum) belong to the Gempylidae family (gemfish) and are the only species of their respective genera ${ }^{1}$. Even though, according to FishBase, there are currently about 24 fish species under the family Gempylidae, only these two species may induce purgative effects, due to their high content of indigestible wax esters (approximately $20 \%$ of their wet weight $)^{2,3}$. In fact, when these fishes are eaten, the wax esters, called Gempylotoxin, accumulate in the rectum, causing a particular type of oily diarrhea, called keriorrhoea ${ }^{4}$. For this reason, oilfish and escolar have been responsible for several food poisoning outbreaks ${ }^{1,5}$. Although keriorrhoea is not life-threatening, it can be risky for people with bowel sensitivity and pregnant women $^{5}$.

Misidentification and mislabeling can occur throughout the entire supply chain. However, on the basis of the available data, it seems that in most cases the toxic gemfish are substituted at the catering level. In particular, frauds take place in the sushi venues, when oilfish and escolar are sold as fillets or slices, therefore becoming difficult to identify on the basis of their morphological characteristics. Gemfish are often substituted to high valued species, such as tunas (Thunnus spp.) and cod (Gadus spp.) or sold as "gindara-snowfish", a term commonly used for sablefish (Anoplopoma fimbria) (Table 1SM), due to the fact that they have the same characteristic white meat ${ }^{6}$. Moreover, in this study we took into consideration also Allothunnus spp., Auxis spp. Euthynnus spp., and Katsuwonus spp. since the term "tunas" can also be used for tuna-like species belonging to these genera ${ }^{7}$.

Due to the health problems associated with gemfish, Japan and Republic of Korea have banned it from the market, while other countries have issued health advisories ${ }^{1,5}$. In particular, in the European Union, "fresh, prepared and processed fishery products belonging to the family

Gempylidae, in particular R. pretiosus and L. flavobrunneum, may only be placed on the market in wrapped/packaged form and must be appropriately labelled to provide information to the consumers on preparation/cooking methods and on the risk related to the presence of substances 
with adverse gastrointestinal effects. The scientific name must accompany the common name on the label as well ${ }^{\prime \prime 8}$. Therefore, a proper identification of these species is required in order to protect consumers from commercial and health frauds.

Although DNA based methods are largely used for fish species authentication ${ }^{9}$, to date only few protocols have been developed to identify these two toxic gemfish species. So far, Ling et al. ${ }^{10}$ developed a DNA sequencing procedure, while Nebola ${ }^{11}$ proposed a PCR-RFLP technique. Recently, a TaqMan® Multiplex Real-time PCR assay for the identification of L. flavobrunneum and $R$. pretiosus has been proposed ${ }^{12}$.

In this work a simple Conventional Multiplex PCR assay was developed for the daily application in laboratory. This method, by permitting to distinguish the two toxic gemfish from the other species (cod, tunas and sablefish) allows to combat health frauds by reducing the long workflow of execution and high-costs often associated to the aforesaid DNA based methods.

\section{Materials and Methods}

\section{Samples collection}

Reference samples. 89 Fresh, ethanol-preserved or dried tissue samples of target species belonging to Gempylidae (R. pretiosus and L. flavobrunneum), Scombridae (Thunnus spp., Euthynnus spp., Katsuwonus spp., Auxis spp. and Allothunnus spp.), Gadidae (Gadus spp.) and A. fimbria were collected. Moreover, 58 other samples of non-target species belonging to Gadidae and Gempylidae and other species replaced with gemfish, such as Xiphias gladius, Scomber spp. and Dissostichus spp. have been considered. Reference samples were kindly provided by Research Institutes or directly collected in this study (Table 1).

Sushi samples. Species commonly used for the preparation of sushi and sashimi were also analyzed: in particular, 40 DNA sushi samples made of "white meat" fish species (10 Sparus aurata, 10 Dicentrarchus labrax,10 Atheresthes stomias, 10 Solea solea), collected and molecularly identified in another ongoing study, were tested (Table 1).

\section{DNA extraction and evaluation}


The ethanol-preserved samples were re-hydrated in $100 \mathrm{mM}$ TRIS-base $(\mathrm{pH} 7.8)$ for $30 \mathrm{~min}$ at

room temperature. Total DNA extraction was performed from at least $20 \mathrm{mg}$ of tissue following the protocol proposed by Armani et al. ${ }^{13}$. The amount of DNA was determined with a NanoDrop ND1000 spectrophotometer (NanoDrop Technologies, Wilmington, DE, USA) by measuring the absorbance at $260 \mathrm{~nm}$.

\section{Primers projecting}

Initially, 20 sequences (when available) of the mitochondrial Cytochrome Oxidase subunit I (COI) gene of all the species included in the study were randomly selected among those available in GenBank and BOLD (Table 2SM).

Parameters considered during primer design. High quality primers were designed considering three main parameters: (i) the specificity of the primers towards the target sequence, that is the ability of the primers to amplify only the intended target (and obviously not to amplify any unintended ones) by only matching to the target sequence. The selection of the conserved or polymorphic regions for designing common or genus-specific primers was carried out by aligning the sequences with Clustal $\mathrm{W}$ in BioEdit version 7.0.9 $9^{14}$. In particular, (when possible) specific primers with at least 3 mismatches were designed; (ii) the amplicon length, which has to be different between target DNA of at least 50bp, in order to easily discriminate them on an electrophoresis gel, was also selected taking into consideration the level of DNA degradation of the samples to analyze. In fact, DNA degradation has also been observed in fresh and frozen products $^{15,16}$; (iii) the annealing score assigned by the Multifunctional Oligo Property Analysis Tool (MOPS) (available at https://ecom.mwgdna.com/services/webgist/mops.tcl) on the basis of the primers overall characteristic (melting temperature, GC content, molecular weight, extinction coefficient and tendency to form dimers). Only the primers with a score lower than 15 were chosen.

Specific primers were produced for the amplification of target regions on the COI gene for gemfishes, sablefish, and tunas. On the contrary, due to the impossibility to design high quality primers on this gene, the cytb gene was selected as alternative target for cod species. Also in this 
131 case, the primers were designed on the basis of the aforesaid parameters. Moreover, the possibility

132 to choose the $c y t b$ gene instead of the $C O I$ gene for satisfying the specific requests was evaluated

133 through a intra and inter-specific analysis of both the COI and $c y t b$ sequences of cod species and of

134 other related Gadidae species (Table 2SM). In details, their pairwise distances was calculated with

135 the Kimura's two parameter model ${ }^{17}$, using the software MEGA $6.0^{18}$.

136 Genera-specific and Species-specific primers targeting the COI and the cytb genes. As for the

137 COI gene, one degenerated common forward primer (For-COI) and 4 reverse primers (Gem-COIR,

138 Sable-COIR.1, Sable-COIR.2 and Tunas-COIR) were produced (Table 2). With regard to the cytb

139 gene, three forward primers (Cod-cytbF, Cod-cytbF.1 and Cod-cytbF.2) and one reverse primer

140 (Cod-cytbR) were designed (Table 2).

141 Control PCR Primers Targeting the $16 S$ rRNA Gene. With the aim of amplifying a control

142 fragment shorter than the specific bands of all the species considered, three pairs of $16 \mathrm{Sr} R N A$

143 primers have been designed (Table 2).

\section{Primers assessment and final multiplex PCR protocol}

Primers assessment and selection. The amplification specificity of both COI and cytb primers was preliminarily evaluated before mixing them together in a multiplex reaction. In the case of the COI, the common forward primer (For-COI) was tested on the DNA of all the target reference species in a single reaction with each of the reverse primers designed. In the same way, the $c y t b$ forward and the cytb reverse primers were tested on all the target DNA samples of the species included in the study. The primers able to amplify the target sequences were then tested on the DNA of all the non-target species, in order to verify their specificity. Thus, the primers that did not produce unspecific bands were selected and mixed together. In the same way, the three couples of $16 S r R N A$ control primers were initially tested on all the reference DNA samples, in order to assess the best one. During the first multiplex reaction trial, in which the $16 S r R N A$ control primers have not been included, all the specific $C O I$ and $c y t b$ primers were used at the same concentration (150 $\mathrm{nM}$ ). Subsequently, the concentrations were modified with the aim to obtain bands of similar 
157

158

159

160

161

162

163

164

165

166

167

168

169

170

171

172

173

174

175

176

177

178

179

180

181

182

intensity. During this analytical step, which still did not include the $16 S \mathrm{r} R N A$ control primers, the best concentration of each specific primer was set (range 75-400 nM). Therefore, the selected couple of $16 \mathrm{~S} r R N A$ control primers (16Sfor.3 and 16Srev.3) (Table 2) was included in the multiplex reaction after different concentration trials (from 100 to $200 \mathrm{nM}$ ). Finally, the concentration of both COI/cytb specific and 16s rRNA control primers was further finely adjusted.

Final Multiplex PCR protocol. The following final Multiplex PCR protocol has been selected: 20 $\mu \mathrm{L}$ of reaction volume containing $2 \mu \mathrm{L}$ of $10 \times$ buffer (Fisher Molecular Biology, Trevose PA, U.S.A.) with the standard concentration of $\mathrm{MgCl}_{2}(1.5 \mathrm{mM}), 400 \mu \mathrm{M}$ of each $\mathrm{dNTP}$ (dNTPmix, Euroclone S.p.A-Life Sciences Division, Pavia, Italy), $400 \mathrm{nM}$ of FORC1, $150 \mathrm{nM}$ of Gem-COI, $325 \mathrm{nM}$ of Sable-COI2, $125 \mathrm{nM}$ of Tunas-COI, $35 \mathrm{nM}$ of Cod-CytbF.2, $35 \mathrm{nM}$ of Cod-CytbR, 160 $\mathrm{nM}$ of 16Sfor.3 and $160 \mathrm{nM}$ of 16Srev.3, $25 \mathrm{ng} / \mu \mathrm{L}$ of BSA (Purified BSA 100×, New England BIOLABS Inc. Ipswich, MA, U.S.A.), 1 U of PerfectTaq DNA Polymerase (5Prime, Gaithersburg, USA), $50 \mathrm{ng}$ of DNA and DNase free water (Water Mol. Bio. Grade, DNase-RNase and Protease free, 5Prime GmbH, Hamburg, Germany) with the following cycling conditions: denaturation at 94 ${ }^{\circ} \mathrm{C}$ for $3 \mathrm{~min} ; 40$ cycles at $94{ }^{\circ} \mathrm{C}$ for $20 \mathrm{~s}, 48^{\circ} \mathrm{C}$ for $25 \mathrm{~s}$, and $72{ }^{\circ} \mathrm{C}$ for $10 \mathrm{~s}$; final extension at $72{ }^{\circ} \mathrm{C}$ for 5 min. The amplified PCR products were visualized by standard gel electrophoresis in a $4 \%$ agarose gel (GellyPhor, Euroclone).

Validation of the final multiplex PCR on sushi samples. The developed final multiplex PCR assay was tested for validation on the DNA samples of white meat species used in sushi production (species reported in white boxes in Table 1).

\section{Amplification of the COI and cytb genes from reference DNA samples of target species.}

The COI and cytb genes were amplified from 53 samples of DNA of the species extracted in this study according to the gene selected (see section Parameters considered during primer design). In particular, the primers FISH-BCL (5'-TCAACYAATCAYAAAGATATYGGCAC-3') and FISHBCH (5'-ACTTCYGGGTGRCCRAARAATCA-3' $)^{19}$, tailed with M13 by Steffens ${ }^{20}$ were selected for the amplification of a fragment of $\sim 700 \mathrm{bp}$ of the COI gene of 45 DNA samples and the primers 
GluFish-F (5'-AACCACCGTTGTTATTCAACTACAA-3') and THR-Fish-R (5'ACCTCCGATCTTCGGATTACAAGACC-3' $)^{21}$ were used to amplify a region of 1235 bp, including the $c y t b$ gene of 8 DNA samples. In the case of the $c y t b$ gene, the samples that failed the amplification were subsequently amplified using internal reverse primer CytBI-4R (5'AGGAAGTATCATTCGGGCTTAATATG-3') ${ }^{21}$ in combination with the same forward primer. The reaction solution was $20 \mu \mathrm{L}$ in volume and contained $2 \mu \mathrm{L}$ of $10 \times$ buffer (5Prime, Gaithersburg, USA) including $1.5 \mathrm{mM} \mathrm{MgCl} 2,200 \mu \mathrm{M}$ dNTPs (dNTPmix, Euroclone S.p.A-Life Sciences Division, Pavia, Italy), $300 \mathrm{nM}$ each primer, $25 \mathrm{ng} / \mu \mathrm{L}$ BSA (Purified BSA 100×, New England BIOLABS ${ }^{\circledR}$ Inc. Ipswich, MA, USA), 1.25 U PerfectTaq DNA Polymerase (5Prime, Gaithersburg, USA), 100 ng DNA and DNase free water (Water Mol. Bio. Grade, DNase-RNase and Protease free, 5Prime GmbH, Hamburg, Germany), according to the following PCR cycling profile:

\section{COI gene: denaturation at $94^{\circ} \mathrm{C}$ for $3 \mathrm{~min} ; 45$ cycles at $94^{\circ} \mathrm{C}$ for $30 \mathrm{~s}, 53^{\circ} \mathrm{C}$ for $30 \mathrm{~s}, 72^{\circ} \mathrm{C}$ for 35} $\mathrm{s}$; final extension at $72^{\circ} \mathrm{C}$ for $10 \mathrm{~min}$.

cytb gene: denaturation at $94^{\circ} \mathrm{C}$ for $3 \mathrm{~min} ; 45$ cycles at $94^{\circ} \mathrm{C}$ for $25 \mathrm{~s}, 55^{\circ} \mathrm{C}$ for $25 \mathrm{~s}, 72^{\circ} \mathrm{C}$ for 45 $\mathrm{s}$; final extension at $72^{\circ} \mathrm{C}$ for $10 \mathrm{~min}$.

Five $\mu \mathrm{L}$ of PCR products were checked by electrophoresis on a $2 \%$ agarose gel and the presence of expected amplicons was assessed by a comparison with the standard marker SharpMass ${ }^{\mathrm{TM}} 50$ DNA ladder (Euroclone, Wetherby, UK). PCR products were purified and sequenced by HighThroughput Genomics Center (Washington, USA). The obtained sequences were analyzed as reported in Armani et al. ${ }^{22}$ and deposited on GenBank via EBI. Overall, 51 sequences have been deposited (43 of the COI gene and 8 of the $c y t b$ gene) (Table 1). The comparison of these sequences with those available on the databases, the purpose of which was to assess their reliability, was carried out by a BLAST analysis on GenBank (http://blast.ncbi.nlm.nih.gov/Blast.cgi) and, only for COI gene sequences, also using the Identification System (IDS) on BOLD (Species Level Barcode Records) (http://www.boldsystems.org/index.php/IDS_OpenIdEngine). Moreover, all these 
sequences were also analyzed with those retrieved from the databases and evaluated to verify the presence of polymorphisms that could affect primers' annealing specificity.

\section{Results and Discussion}

\section{Selection of the target species}

Among the DNA-based analysis methods, multiplex PCR is one of the preferred technique, due to its rapidity and simplicity of execution and to the fact that it can identify more than one species in a single reaction ${ }^{23}$. However, the number of species included in the assay undoubtedly influences its effectiveness. In fact, the amount of primers utilized in the reaction mix should not be too high, to avoid dimer formation and consequently negatively influence the amplification output. Therefore, considering that a selective preliminary choice of the target species represented one of the most important step to develop an efficient identification method, we planned the assay in order to only include the species with a high probability to be involved in the fraud.

Gemfish. R. pretiosus, L. flavobrunneum, T. atun, and R. solandri are the only commercial species in the Gempylidae family (fishbase.org), but, among them, only $R$. pretiosus and $L$. flavobrunneum are toxic ${ }^{1}$ and frequently commercialized. For this reason, they were primarily chosen as toxic target species for the assay. Then, other species more frequently reported as replaced by toxic gemfishes were also selected (Table 1SM).

Tunas: tuna and tuna-like species. Considering that the term tunas can be used to indicate tunafish and other similar species, such Allothunnus spp., Auxis spp., Euthynnus spp. and Katsuwonus spp. ${ }^{7}$, other than Thunnus spp. we included all the aforesaid genera as target.

Originally, the most common type of tuna served in Japanese sushi and sashimi was the bluefin tuna, which encompasses three distinct species: southern bluefin tuna (Thunnus maccoyii), pacific bluefin tuna (Thunnus orientalis), and northern bluefin tuna (Thunnus thynnus) ${ }^{24}$. However, after the alarming depletion of these species and the declaration of the International Union for Conservation of Nature (IUCN), which regarded bluefin stocks as endangered (http://www.iucnredlist.org/search), species such as Thunnus alalunga (albacore tuna), Thunnus 
235

236

237

albacares (Yellowfin tuna), and Thunnus tonggol (Longtail tuna) have started to be widely exploited. These three species meat have a very light yellow or an almost white color, particularly in the case of $T$. alalunga, which is marketed as "white tuna" (http://www.atuna.com/index.php/tuna-info/tuna-species-guide). Therefore, they can be easily replaced with gemfishes. A recent study of Warner et al. ${ }^{25}$ reported that $84 \%$ of the "white tuna" samples collected in the U.S. sushi restaurants were actually L. flavobrunneum. However, it is important to point out that tuna-sushi preparations can also include species not properly belonging to the genus Thunnus, but belonging to tuna-like species, such as Allothunnus, Auxis, Euthynnus, and Katsuwonus. The latter, in particular, is considered the seventh principal market tuna species after T. alalunga, T. obesus, T. thynnus, T. orientalis, T. maccoyii and $T$. albacares (ftp://ftp.fao.org/docrep/fao/007/y5852e/Y5852E18.pdf) and in sushi restaurants is commonly known as Katsuo (鰹).

It is interesting to note that gemfishes have often been sold instead of tunas due to their frequent bycatch in tuna fisheries ${ }^{24}$. In fact, it has been stated that oilfish and escolar, which were distributed almost worldwide (Fishbase.org), constituted more than $70 \%$ of the bycatch in this fishery ${ }^{26}$. This supports the hypothesis that part of these toxic species, often banned from the international markets, could enter into the supply chain in form of disguised products.

Cod species. According to a more general classification, the denomination "cod" refers to all the fishes in the family Gadidae ${ }^{27}$; on the contrary, the ASFIS list and Fishbase (http://www.fao.org/fishery/collection/asfis/en) requires a specific name for each species: atlantic cod for G. morhua, pacific cod for G. macrocephalus and Greenland cod for G. ogac. Thus, we decide to include in the assay only the "true cod" species belonging to the genus Gadus, which are G. morhua, G. macrocephalus and G. ogac. In fact, as for the tunas species (see section Tunas: tuna and tuna-like species) the Gadus spp. is very likely to be replaced, due to the color of its meat, which is very similar to that of the gemfishes ${ }^{28}$. In particular, on the basis of the data available (Table 1SM), it seems that in the most part of the cases the gemfishes are substituted to the high 
261 valued atlantic $\operatorname{cod}^{29,30}$ even though they are often also marketed with fake names, such as southern 262 cod, canadian cod, $\operatorname{codfish}^{31}$ or ruddercod $^{10}$. Moreover, as reported by a recent study ${ }^{16}$, a very high rate of mislabeling has been highlighted in seafood products sold as cod (or denomination similar to cod), which have often been replaced with other species of Gadiformes, but also with the species

265

Dissostichus spp. and with sablefish.

Sablefish. We decided to include in the assay also the species A. fimbria (Order: Scorpaeniformes; Family: Anoplopomatidae), better known in the market as "sablefish" or improperly defined as "black cod" (www.fishbase.org). Sablefish is an economically important ground fish species inhabiting the continental shelf and slope of the North Pacific Ocean and the Bering Sea. It has long been popular in Japan, which is presently the world largest market for sablefish, and in the last decade the popularity of this species has highly grown in American restaurants, and stores (http://www.nytimes.com/2004/09/22/dining/22SABL.html?_r=0), where is best known as "smoked sable" in New York delis, "smoked black cod" in the Pacific Northwest (even though it is not related to codfish) (http://fishcooking.about.com/od/meetyourfish/p/sablefish.htm) or "gindara" at sushi venues level (http://www.thefishsociety.co.uk/shop/gindara-sushi-black-cod.html). However, most of the U.S. supply is exported, chiefly to Japan, in frozen form, where Japanese buyers sell it for sashimi ${ }^{32}$. Also for this species, the white color of the meat facilitate the illicit substitution with gemfishes ${ }^{6}$ (Table 1SM). Despite the market for sablefish is primarily in Japan, China (Hong Kong), U. S. and Canada, this species has been considered as target for the assay due to the fact that it is increasingly involved in the European markets (http://www.bcseafood.ca/PDFs/fisheriesinfo/fisherysablefish.pdf) and due to the chaos arising from the commercial term used to identify it. In fact, in a recent work ${ }^{16}$, all the products sold under the Chinese name used for A. fimbria were identified as Dissostichus spp.

\section{Selection of the non-target species}


Related species of the Gempylidae and Gadidae families were collected. In particular, three nontoxic commercial species of the family Gempylidae (Thyrsites atun, Rexea solandri and Rexea prometheoides) were included in the study in order to increase the specificity of the assay; in this way, an intra-family distinction between toxic and non-toxic species was also possible. Moreover, six highly commercial species of the family Gadidae (the so called cod-related species) were included in the study: Theragra chalcogramma (Alaska pollock), Melanogrammus aeglefinus (haddock), Microgadus proximus (pacific tomcod), Pollachius virens (saithe), Merlangius merlangus (whiting), Micromesistius poutassou (blue whiting). All these species have been reported to be deliberately or unintentionally substituted with the "true cod" species, due to their similar organoleptic and morphological characteristics ${ }^{16,33}$. We did not include them in the assay as target species, in order to discriminate high valuable species from less valuable species. Moreover, other species (Xiphias gladius, Scomber spp. and Dissostichus spp.) (Table 1 and Table 1SM) seldom replaced with gemfishes were used. In particular, the species Dissostichus spp. (commonly known as patagonian toothfish), as well as the sablefish, has been reported as often improperly sold as $\operatorname{cod}^{16}$. Therefore, the inclusion of this species can further improve the assay with the possibility to identify frauds due to the misuse of the term cod.

White meat species used in sushi preparation. In addition, white meat species used in the preparation of sushi and sashimi in Asian restaurants in Italy, such as gilthead seabream (Sparus aurata), seabass (Dicentrarchus labrax), and two species of flat fish, such as Atheresthes stomias and Solea solea were also included in the study. Even though, to the best of our knowledge, no mislabeling have been reported for these latter four species, we cannot exclude the possibility that this kind of fraud may occur, due to the similarity of their meat with that of toxic gemfishes.

\section{DNA gene markers and primer design}

Among the different DNA markers used for fish species identification, mitochondrial DNA (mtDNA) has several advantages over nuclear DNA ${ }^{9,34}$. 
To date, the most commonly used mitochondrial genes are COI, cytb and $16 S r R N A^{9}$. While the $16 S$ rRNA gene is usually used for phylogenetic studies at mid-categorical levels, such as in families or rare genera, due to a lower inter-species variability ${ }^{35}$, the $C O I$ and $c y t b$ genes, due to their comparable high inter-species variation and low intra-species variation, are the most widely used genetic markers for fish species identification and they have been used in a large number of studies applied to food inspection ${ }^{15,16,36,37}$. However, the introduction of DNA barcoding has determined a growth in the use of the COI gene as a genetic marker for species identification and for biodiversity analysis, with respect to the gene $c y t b^{38}$.

Therefore, due to the fact that the $16 S \mathrm{r} R N A$ gene is characterized by a low mutation rate, we decided to use it for the designing of the control primers. On the contrary, for the specific primers, we initially decided to choose the COI gene, due to the fact that its 700 bp polymorphic sequence has been largely used to discriminate closely related fish species ${ }^{15,16,27,36}$. Unfortunately, high scored primers (see section Primers assessment and selection) were easily obtained for gemfishes, sablefish, and tunas, but not for cod species. This might be attributed to the fact that the retrieved COI sequences were too short for containing enough polymorphic regions. In fact, the probability of finding polymorphic regions and their number is proportional to the length of the target sequences $^{39}$. Therefore, for cod identification, the $c y t b$ gene was selected, since available sequences exceeded $1000 \mathrm{bp}$. This allowed to design high quality primers able to discriminate Gadus spp. from the other non-target species of the Gadidae family. Moreover, the inter-specific analysis values between the cytb sequences of Gadus spp. and the other cod-related species considered in the assay showed an higher percentage of variability (12\%) respect to the COI gene (9\%). One of the main points to take into consideration during the setting up a multiplex PCR is to design primers that both guarantee to specifically distinguish between different DNA target with an acceptable level of amplification efficiency. Obviously, the higher the number of mismatches within non-target species sequences, the better the specificity of the primer. 
With regards to the mismatches position, several studies have shown that mismatches towards

the 3 'end of the primer affect the amplification performance much more than mismatches towards the 5 ' end $^{22,40,41,42}$. Thus, we tried to design primers with mismatches near the 3 'end of non-target species (Table 3SM). Moreover, all the primers were designed to amplify fragments of different length (range 115-479 bp) (see section Specie-specific primers targeting the COI and cytb genes.

), in order to be able to distinguish the specific bands on the electrophoresis gel. Finally, considering that several studies reported high level of degradation even in case of fresh/frozen products $^{15,16}$, the longest amplicon obtainable was set at $479 \mathrm{bp}$.

All the sequences produced in this study showed a very high identity degree with those available on the database (Table 1) and no mutations were found on the annealing region of the primers. Unfortunately, no high quality sequences were obtained from the DNA sample belonging to Allothunnus fallai and Thyrsites atun. However, since the fact that these DNA sample gave the expected band when tested under the amplification condition of the Multiplex PCR assay, we have hypothesized that no many differences might exist between the available sequences and the samples we collected.

Specie-specific primers targeting the COI and cytb genes.

Considering the variability of the COI gene among the families considered, which makes difficult to find a common conserved region among different genera, we decided to design a degenerate primer (FOR-C1). The possibility to use a common forward primer highly decrease the probability of template-independent primer interactions during amplification, especially in the case of a multiplex $\mathrm{PCR}^{23,39,43}$. On the contrary, the reverse primers were designed on the polymorphic regions of the COI gene. In particular, the selected COI primers allowed to specifically amplify: a COI fragment gene of 479 bp from both the toxic gemfish species ( $R$. pretiosus and $L$. flavobrunneum); of $403 \mathrm{bp}$ from A. fimbria; and of $291 \mathrm{bp}$ from tunas species included in the assay. As for the cytb gene, the selected couple of specific primers allowed to specifically amplify a fragment of $193 \mathrm{bp}$ from all the three cod species (G. microcephalus, G. morhua, G. ogac) (Figure 
362 1). As reported in Table 2, the selected forward cytb primer (Cod-cytbF.2) was obtained by the 363 modification of Cod-cytbF.1. In particular, the primer selected had a bp different from the previous 364 one different that allowed a greater degree of mismatch with the non-target species (Table 3SM).

Control primers targeting the $16 S$ rRNA gene. Three primer pairs 16Sfor and 16Srev were

designed relying on the high level of identity among all the Gempylidae, Gadidae, Scombridae, and other non-target species and "white meat" species (see section 3.2.1), after comparing all the sequences retrieved. All the control primers were designed to produce bands shorter than the speciespecific bands and obtainable even in case of extremely degraded DNA. In the end, the couple 16Sfor.3/16Srev.3 (amplicon length=115 bp) (Table 2) was the best in terms of amplificability and specificity. Even though the control amplicon was shorter than those produced by the specific primers, it was clearly distinguishable from the unspecific dimerization of other primers, thanks to the utilization of a $4 \%$ agarose gel. In fact, as already found ${ }^{23,44}$, the choice of the most appropriate gel concentration is a fundamental parameter that can enhance the interpretation of the outcomes.

\section{Multiplex PCR Assay: optimization and final protocol}

Primers concentration and annealing temperature. During the first multiplex reaction trial (see section Primers assessment and selection), where all the COI and cytb specific primers were used at the same concentration $(150 \mathrm{nM})$, the amplification output was very different between the $C O I$ and the cytb primers. In fact, while for the latter the band intensity was good (with a concentration higher than $70 \mathrm{ng} / \mu \mathrm{l}$ ) estimated by the comparison with the bands produced by the standard electrophoresis ladder, for the COI primers it was slighter (35 ng/ $\mu 1$ or less) or, in some cases, not even perceivable. For this reason, we initially increased the concentration of the For-COI.1, mainly because the same forward primer was coupled with three different reverse primers (Gem-COIR, Sable-COIR.2, Tunas-COIR). Amplicons were obtained from all the samples with a For-COI concentration of $400 \mathrm{nM}$. However, the COI bands still resulted slighter than the cytb band. Therefore, the concentrations of all the reverse COI primers were subsequently modified with the aim to obtain bands of similar intensity ( $70 \mathrm{ng} / \mu 1$ for each band at least) with the $c y t b$ band. In this 
way, all the specific primers produced the expected amplicon and no unspecific bands were observed. However, we found that the introduction of the $16 S r R N A$ control primers considerably upset the reaction output. In particular, if they were included in the reaction mix in a concentration lower than $150 \mathrm{nM}$, the control bands did not appeared. On the contrary, a concentration higher than $175 \mathrm{nM}$ determined the disappearance of some specific bands. Therefore, we have done several trials in order to assess the appropriate final concentration. In fact, even when theoretically high quality primers are produced, their relative concentration in the final mix must be adjusted to obtain the expected outcomes ${ }^{43}$. Finally, the optimum reaction output was obtained with a concentration of $160 \mathrm{nM}$ for the $16 S \mathrm{SRNA}$ control primers combined with a substantial lowering of both the COI and $c y t b$ primers (50 $\mathrm{nM}$ for the forward and $35 \mathrm{nM}$ for the reverse). The melting temperature of COI, cytb and $16 S$ rRNA primers was in the range of $47.5^{\circ} \mathrm{C}-54.3^{\circ} \mathrm{C}$ (Table 2). Finally, an annealing temperature of $48^{\circ} \mathrm{C}$ was selected due to the higher band intensity obtained from all the DNA target samples (Figure 1). In this conditions, the bands were easily detectable on the gel and with a similar intensity, with a DNA concentration of about $70 \mathrm{ng} / \mu 1$.

Validation of the final multiplex PCR on sushi samples. Once tested on the market sushi samples, made of the white meat species (Table 1), no amplification bands were obtained other than the control bands.

\section{Public health implication related to seafood mislabeling}

With the dynamic of cross cultural and inter-geographical food exchange, which is largely supported by technological advances in food industry ${ }^{9}$, the Japanese cuisine, and in particular the sushi and sashimi culture, has been uniquely developed almost worldwide ${ }^{45}$. However, the removal of morphological characteristics induced by preparation of these products, together with the continuous entrance of new exotic species, represents the main challenges in seafood identification by Food Business Operators (FBOs), consumers and official controllers ${ }^{36}$.

Few years ago, Lowenstein et al. $^{24}$, stated that "a piece of sushi has the potential to be an endangered species, a fraud, or a health hazard". This statement has been proved extremely 
414 truthful by some studies available to date ${ }^{25,46}$, which reported an high number of mislabeling at the 415 catering level. In most of the cases, it consists in replacing valuable species with cheaper ones ${ }^{9}$, but 416 mislabeled fish can represent a health concern when the replacing is done with toxic species ${ }^{47,48}$.

417 At present, with the progressive depletion of fish stocks of the most requested species, it is 418 increasingly likely that "disguised toxic fish" may enter the food chain under false name. In fact, not 419 only gemfishes have been mislabeled, but also other toxic species such the spanish mackerel labeled as kingfish or puffer fish sold as squid or $\operatorname{cod}^{16,36}$.

Even though health frauds are less frequent than commercial frauds, due to the health implications for the consumers that often required hospitalization, gemfishes are good candidates

423 for voluntary frauds. In fact, the Gempylotoxin may determine consequences that are mild in most 424 cases, with gastrointestinal symptoms that commonly arise only in people with bowel sensitivity ${ }^{5}$. 425 Furthermore, the symptoms are seldom long lasting and absolutely hardly deadly, contrarily to the puffer fish, whose heat stable tetrodotoxin (TTX) is potentially deadly with a minimum lethal dose, which in all adult human is estimated to be only $2-3 \mathrm{mg}^{49}$. This aspect leads us to conjecture that the number of mislabeling cases currently reported could be underestimated, even due to the fact that, in case of sushi products, the portion of fish is very small and it hardly makes consumers sick.

For this reason, while all the fish belonging to the family Tetraodontidae must not be placed on the EU market ${ }^{50}$, for fishes belonging to Gempylidae family this prohibition does not exists, yet, although health advisories have been issued ${ }^{8}$. For the aforesaid reasons, the availability of a rapid method for the authentication of fish products represents a pivotal aspect for the accurate labeling of seafood species and for the protection of consumers' health.

In the light of a growing globalization of seafood trade and of an increased call for safety and quality requirements, margins for mislabeling and health frauds for substitution can be significantly reduced by the use of DNA based analytical techniques, able to properly identify fish species and thus support traceability verification. This is the case of the simple Conventional Multiplex PCR 439 developed in this study, which can be used even in routinely applications to identify not only the 
toxic gemfish species, but also the other most common replaced species, such as cod, tunas and sablefish. This method, which may be considered a valuable aid to combat health frauds, may be also useful to better outline and understand the mechanisms related to the chaos affecting the commercialization of cod products.

\section{Acknowledgments}

The Authors wish to sincerely thank all the people who kindly provided reference tissues of fish species utilized in this study: Dr. Florian Borutta of Institute of Metabolic Physiology, HeinrichHeine-Universitaet (Duesseldorf, Germany); Dr. Mike Canino of Alaska Fisheries Science Center NOAA/NMFS (Seattle WA, USA); Dr. Daniel Curran of NOAA Fisheries, Pacific Islands Fisheries Science Center (Honolulu H,I USA); Dr. Simeon Deguara, Federation of Maltese Aquaculture Producers (Valletta, Malta); Dr. Vinicius Tavares Kütter of Departamento de Geoquimica, Universidade Federal Fluminense (Niterói, Brasil); Dr. William Ludt of Museum of Natural Science, Louisiana State University (Baton Rouge LA, USA); Dr. Renato Malandra of Local Health Authority of Milan (Milan, Italy); Dr. Katherine Maslenikov of University of Washington Fish Collection (Seattle WA, USA); Dr. Jennifer Ovenden of School of Biomedical Sciences, University of Queensland (St Lucia QLD, Australia); Dr. Nikolay Panichev of Department of Chemistry, Tshwane University of Technology (Pretoria, South Africa); Dr. Eric Parent of Fisheries and Oceans, Maurice Lamontagne Institute (Mont-Joli Qc, Canada); Prof. Hiroshi Sato of Joint Faculty of Veterinary Medicine Yamaguchi University (Yoshida, Japan); Dr. Kwang-Tsao Shao of Biodiversity Research Center, Academia Sinica (Taipei, Taiwan); Dr. Amaya Velasco and Dr. Carmen González Sotelo of Departamento de Bioquímica de Alimentos, Instituto de Investigaciones Marinas CSIC (Vigo, Spain); Dr. H.J. Walker of Marine Vertebrate Collection Scripps Institution of Oceanography, University of California (La Jolla CA, USA); Dr. Nicholas C. Wegner of NOAA Fisheries, Southwest Fisheries Science Center (La Jolla CA, USA); Dr. Vanessa White of NOAA Fisheries - Alaska Fisheries Science Center (Seattle WA, USA); Dr. Ryosuke 
Yazawa of Department of Marine Biosciences, Tokyo University of Marine Science and

Technology (Tokyo, Japan).

\section{Supporting information description}

Table 1SM. Studies reporting cases of fish species substitution with Gemfish.

Table 2SM. Species included in this study and corresponding COI and cytb sequences retrieved from GenBank and BOLD.

Table 3SM. Alignment between the COI and cytb primers designed in this study and the available COI and cytb gene sequences of the species included in this work. Mismatches are highlighted in grey. NAS: Not Available Sequences.

\section{References}

1. Alexander, J.; Autrup, H.; Bard, D.; Carere, A.; Costa, L. G.; Cravedi, J. P.; di Domenico, A.; Fanelli, R.; Fink-Gremmels, J.; Gilbert, J.; Grandjean, P.; Johansson, N.; Oskarsson, A.; Renwick, A.; Ruprich, J.; Schlatter, J.; Schoeters, G.; Schrenk, D.; van Leeuwen, R.; Verger, P. Opinion of the Scientific Panel on Contaminants in the Food Chain on a request from the Commission related tothe toxicity of fishery products belonging to the family of Gempylidae. EFSA J. 2004, 92, 1-5.

2. Cox Jr, W. M.; Reid, E. E. The chemical composition of oil of Ruvettus pretiosus, the "castor oil fish". J. Am. Chem. Soc., 1932, 54 (1), 220-229.

3. Nichols, P. D.; Mooney, B. D.; Elliott, N. G. Unusually high levels of nonsaponifiable lipids in the fishes escolar and rudderfish: identification by gas and thin-layer chromatography. J. Chromato. A. 2001, 936 (1), 183-191.

4. Berman, P.; Harley, E. H.; Spark, A. A. Keriorrhoea-the passage of oil per rectumafter ingestion of marine wax esters. S. Afr. Med. J. 1981, 59 (22), 791-792.

5. Ling, K. H.; Nichols, P. D.; But, P. P. H. Fish-Induced Keriorrhea. Adv. Food Nutr. Res. 2009, 57, 1-52.

6. $\quad$ Maralit, B. A.; Aguila, R. D.; Ventolero, M. F. H.; Perez, S. K. L.; Willette, D. A.; Santos, M. D. Detection of mislabeled commercial fishery by-products in the Philippines using DNA barcodes and its implications to food traceability and safety. Food Control 2013, 33 (1), 119-125.

7. Majkowski, J. Global fishery resources of Tuna and Tuna-like Species. FAO Fish. Tech. Pap. FAO, Rome, 2007, 483, 54 pp.

8. Commission Regulation (EC) No. 2074/2005 of 5 December 2005, laying down implementing measures for certain products under Regulation (EC) No 853/2004 of the European Parliament and of the Council and for the organisation of official controls under Regulation (EC) No 854/2004 of the European Parliament and of the Council and Regulation (EC) No 882/2004 of the European Parliament and of the Council, derogating from Regulation (EC) No 852/2004 of the European Parliament and of the Council and amending 
Regulations (EC) No 853/2004 and (EC) No 854/2004. OJ L., December 22, 2005, 338, 27 59.

9. Armani, A.; Castigliego, L.; Guidi, A. Fish frauds: the DNA challenge. CAB Rev. 2012, 7 (071), 1-12. 10.1079/PAVSNNR20127071.

10. Ling, K. H.; Cheung, C. W.; Cheng, S. W.; Cheng, L.; Li, S. L.; Nichols, P. D.; Ward, R.D.; Graham, A.; But, P. P. H. Rapid detection of oilfish and escolar in fish steaks: A tool to prevent keriorrhea episodes. Food Chem. 2008, 110 (2), 538-546.

11. Nebola, M.; Borilova, G.; Kasalova, J.. PCR-RFLP analysis of DNA for the differentiation of fish species in seafood samples. Bull. Vet. Inst. Pulawy, 2010, 54, 49-53.

12. Dalama, J.; Vieites, J. M.; Espiñeira, M. Detection of the causal agents of Keriorrhea (Lepidocybium flavobrunneum and Ruvettus pretiosus) by means of Real Time PCR. Food Chem. 2015, 174, 326-329.

13. Armani, A.; Castigliego, L.; Tinacci, L.; Gianfaldoni, D.; Guidi, A. Molecular characterization of icefish (Salangidae family), using direct sequencing of mitochondrial cytochrome b gene. Food Control 2011, 22, 888-895.

14. Hall, T. A. BioEdit: a user-friendly biological sequence alignment editor and analysis program for Windows 95/98/NT. Nucl. Acid. 1999, 41, 95-98.

15. Armani, A.; Guardone, L.; Castigliego, L.; D'Amico, P.; Messina, A.; Malandra, R.; Gianfaldoni, D., Guidi, A. DNA and Mini-DNA barcoding for the identification of Porgies species (family Sparidae) of commercial interest on the international market. Food Control 2015, 50, 589-596.

16. Xiong, X.; Guardone, L.; Giusti, A.; Castigliego, L.; Gianfaldoni, D.; Guidi, A., Armani, A. (2016). DNA barcoding reveals chaotic labeling and misrepresentation of cod (鳕, Xue) products sold on the Chinese market. Food Control 2016, 60, 519-532.

17. Kimura, M. A simple method for estimating evolutionary rate of base substitutions through comparative studies of nucleotide sequences. J. Mol. Evol. 1980, 16, 111-120.

18. Tamura, K.; Stecher, G.; Peterson, D.; Filipski, A.; Kumar, S. MEGA6: molecular evolutionary genetics analysis version 6.0. Mol. Biol. Evol. 2013, 30 (12), 2725-2729.

19. Handy, S.M.; Deeds, J.R.; Ivanova, N.V.; Hebert, P.D.; Hanner, R.H.; Ormos, A.; Yancy, H.F. A single-laboratory validated method for the generation of DNA barcodes for the identification of fish for regulatory compliance. J. AOAC Int. 2011, 94 (1), 201-210.

20. Steffens, D.L.,; Sutter, S.L.; Roemer, S.C. An alternate universal forward primer for improved automated DNA sequencing of M13. BioTechniques 1993, 15 (4), 580-582.

21. Sevilla, R. G.; Diez, A.; Norén, M.; Mouchel, O.; Jérôme, M.; Verrez-Bagnis, V.; Van Pelt, H.; Favre-Krey, L.; Krey, G. ; The Fishtrace Consortium; Bautista, J. M. Primers and polymerase chain reaction conditions for DNA barcoding teleost fish based on the mitochondrial cytochrome band nuclear rhodopsin genes. Mol. Ecol. Notes 2007, 7, 730-734.

22. Armani, A.; Giusti, A.; Guardone, L.; Castigliego, L.; Gianfaldoni, D.; Guidi, A. Universal primers used for species identification of foodstuff of animal origin: effects of oligonucleotide tails on PCR amplification and sequencing performance. Food. Anal. Method. 2015, 1-11.

23. Armani, A.; Giusti, A.; Castigliego, L.; Rossi, A.; Tinacci, L.; Gianfaldoni, D.; Guidi, A. Pentaplex PCR As Screening Assay for Jellyfish Species Identification in Food Products. J. Agr. Food Chem. 2014, 62 (50), 12134-12143. 
24. Lowenstein, J. H.; Amato, G.; Kolokotronis, S. O. The real maccoyii: identifying tuna sushi with DNA barcodes-contrasting characteristic attributes and genetic distances. PLoS One 2009, 4 (11), e 7866.

25. Warner, K.; Timme, W.; Lowell, B.; Hirshfield, M. Oceana study reveals seafood fraud nationwide. Oceana. Reports 2013, http://oceana.org/sites/default/files/reports/National_Seafood_Fraud_Testing_Results_FINAL .pdf (accessed Sept. 23, 2015).

26. Ardill, D.; Itano, D.; Gillett, R. A review of bycatch and discard issues in Indian Ocean tuna fisheries. Indian Ocean Commission and SmartFish. 2011, 1-44.

file://C:/Users/Alice/Downloads/IOTC-2012-WPEB08-INF20\%20(1).pdf (accessed Oct. 3, 2015).

27. Di Pinto, A.; Di Pinto, P.; Terio, V.; Bozzo, G.; Bonerba, E.; Ceci, E.; Tantillo, G. DNA barcoding for detecting market substitution in salted codfillets and battered cod chunks. Food Chem. 2013, 141(3), 1757-1762.

28. Stiles, M. L.; Lahr, H., Lahey, W., Shaftel, E.; Bethel, D., Falls, J.; Hirshfield, M. F. Bait and Switch: how seafood fraud hurts our oceans, our wallets and our health. Oceana Reports 2011, http://oceana.org/sites/default/files/reports/Bait_and_Switch_report_2011.pdf (accessed Oct. 3, 2015).

29. Abelson, J.; Daley, B. On the menu but not on your plate. Boston Globe 2011; http://ibol.org/wp-content/uploads/2011/10/1_On-the-menu-but-not-on-your-plate.pdf (accessed Jul. 21, 2015).

30. Jacquet, J. L.; Pauly, D. Trade secrets: renaming and mislabeling of seafood. Mar. Policy 2008, 32 (3), 309-318.

31. Lam, V. Oilfish-the case of the imitation Atlantic cod. 2007, http://www.seaaroundus.org/newsletter/Issue40.pdf (accessed Jul. 22, 2015).

32. Dore, I. The New Fresh Seafood Buyer's Guide: A manual for distributors, restaurants and retailers. Springer Science \& Business Media, 2013.

33. Herrero, B., Madrinán, M., Vieites, J. M., \& Espiñeira, M. Authentication of Atlantic cod (Gadus morhua) using real time PCR. J. Agr. Food Chem. 2010, 58 (8), 4794-4799.

34. Teletchea, F. Molecular identification methods of fish species: Reassessment and possible applications. Rev. Fish Biol. Fisher. 2009, 19, 265-293.

35. Gerber, A. S.; Loggins, R.; Kumar, S.; Dowling, T. E. Does nonneutral evolution shape observed patterns of DNA variation in animal mitochondrial genomes? Annu. Rev. Genet. 2001, 35, 539-566.

36. Armani, A.; Guardone, L.; La Castellana, R.; Gianfaldoni, D.; Guidi, A.; Castigliego, L. DNA barcoding reveals commercial and health issues in ethnic seafood sold on the Italian market. Food Control 2015, 55, 206-214.

37. Pepe, T.; Trotta, M.; Di Marco, I.; Cennamo, P.; Anastasio, A.; Cortesi, M. L. Mitochondrial cytochrome b DNA sequence variations: an approach to fish species identification in processed fish products. J. Food Protect. 2005, 68(2), 421-425.

38. Arif, I. A.; Khan, H. A. Molecular markers for biodiversity analysis of wildlife animals: a brief review. Anim. Biodivers. Conserv. 2009, 32 (1), 9-17.

39. Armani, A.; Castigliego, L.; Tinacci, L.; Gianfaldoni, D.; Guidi, A. Multiplex conventional and real-time PCR for fish species identification of Bianchetto (juvenile form of 
600

601

602

603

604

605

606

607

608

609

610

611

612

613

614

615

616

617

618

619

620

621

622

623

624

625

626

627

628

629

630

631

632

633

634

Sardina pilchardus), Rossetto (Aphia minuta), and Icefish in fresh, marinated and cooked products. Food Chem. 2012, 133 (1), 184-192.

40. Elkins, K. M. (2011). Designing Polymerase Chain Reaction (PCR) Primer

Multiplexes in the Forensic Laboratory. J Chem Educ, 2011, 88(10), 1422-1427

41. Palumbi, S. R.; Martin, A.; Romano, S.; McMillan, W. O.; Stice, L.; Grabowski, G. The Simple Fool's Guide to PCR, Version 2.0, privately published document compiled by S. Palumbi, 1991, Dept. Zoology, Univ. Hawaii, Honolulu, HI, 96822.

42. Ye, J.; Coulouris, G.; Zaretskaya, I.; Cutcutache, I.; Rozen, S.; Madden, T. L. Primer-BLAST: a tool to design target-specific primers for polymerase chain reaction. $B M C$ bioinformatics 2012, 13 (1), 134.

43. Castigliego, L.; Armani, A.; Tinacci, L.; Gianfaldoni, D.; Guidi, A. Two alternative multiplex PCRs for the identification of the seven species of anglerfish (Lophius spp.) using an end-point or a melting curve analysis real-time protocol. Food Chem. 2015, 166, 1-9.

44. Armani, A.; Castigliego, L.; Tinacci, L.; Gandini, G.; Gianfaldoni, D.; Guidi, A. A rapid PCR-RFLP method for the identification of Lophius species. Eur. Food Res.

Technol. 2012, 235(2), 253-263.

45. Tachibana, R. "Processing” Sushi/Cooked Japan: Why Sushi Became Canadian. Doctoral dissertation, University of Victoria 2008

http://dspace.library.uvic.ca/bitstream/handle/1828/1311/Rumiko\%20Tachibana\%20MA\% 20Thesis.pdf? sequence $=1 \&$ isAllowed=y (accessed Oct. 6, 2015).

46. Stiles, M. L., Kagan, A., Lahr, H. J., Pullekines, E., \& Walsh, A. Seafood Sticker Shock Why you may be paying too much for your fish. Oceana Reports 2013, http://oceana.org/sites/default/files/reports/Oceana_Price_Report.pdf (accessed Oct. 6, 2015).

47. Civera, T. Species identification and safety of fish products. Vet. Res. Commun. 2003, 27, 481-489.

48. De Battisti, C.; Marciano, S.; Magnabosco, C.; Busato, S.; Arcangeli, G.; Cattoli, G. Pyrosequencing as a Tool for Rapid Fish Species Identification and Commercial Fraud Detection. J. Agr. Food Chem. 2013 62(1), 198-205.

49. Noguchi, T; Ebesu, J. S. M. Puffer poisoning: epidemiology and treatment. $J$. Toxicol. Toxin. Rev. 2001, 20, 1-10.

50. Regulation (EC) No 854/2004 of the European Parliament and of the Council of 29 April 2004, laying down specific rules for the organisation of official controls on products of animal origin intended for human consumption. OJ L, April 30, 2004, 226, 83-127.

\section{Figure captions}

Figure 1. Electrophoresis on agarose gel (4\%) of the species selected as target after the Multiplex PCR; the "genus control" band of 115 bp is clearly visible together with the species-specific band. Line 1, Lepidocybium flavobrunneum (479 bp), bp); line 2, Anoplopoma fimbria (403 bp); line 3, Thunnus albacares (291 bp); line 4, Gadus morhua (193 bp); line 5, H2O; lines 1,2,3,4: 16S rRNA positive control bands (115 bp). DNA ladder band size: 1000 bp, 900 bp, 800 bp, 700 bp, 600 bp, 500 bp, 400 bp, 300 bp, 250 bp, 200 bp, $150 \mathrm{bp}, 100 \mathrm{bp}, 50 \mathrm{bp}$. 
635

636

637

638

639

640

641

642

643

644

645

Tables

\begin{tabular}{|c|c|c|c|c|c|c|c|c|c|c|}
\hline \multirow[b]{2}{*}{ Order } & \multirow[b]{2}{*}{ Family } & \multirow[b]{2}{*}{$\begin{array}{c}\text { Genus/sp } \\
\text { ecies }\end{array}$} & \multirow[b]{2}{*}{$\begin{array}{c}\text { Researc } \\
\mathbf{h} \\
\text { Institute }\end{array}$} & \multirow[b]{2}{*}{$\begin{array}{l}\text { Numb } \\
\text { er of } \\
\text { speci } \\
\text { mens }\end{array}$} & \multirow[b]{2}{*}{$\begin{array}{c}\text { FA } \\
\text { O } \\
\text { Ar } \\
\text { ea }\end{array}$} & \multirow[b]{2}{*}{$\begin{array}{c}\text { Tar } \\
\text { get } \\
\text { gen } \\
\text { e }\end{array}$} & \multirow[b]{2}{*}{$\begin{array}{c}\text { Seque } \\
\text { nces }\end{array}$} & \multirow{2}{*}{$\begin{array}{l}\text { GenB } \\
\text { ank } \\
\text { seque } \\
\text { nce } \\
\text { code }\end{array}$} & \multicolumn{2}{|c|}{ BLAST } \\
\hline & & & & & & & & & GenBank & BOLD \\
\hline \multirow{10}{*}{$\begin{array}{c}\text { Gadiforme } \\
\mathrm{s}\end{array}$} & \multirow{10}{*}{ Gadidae } & \multirow{3}{*}{$\begin{array}{l}\text { Gadus } \\
\text { macrocep } \\
\text { halus }\end{array}$} & \multirow{3}{*}{$\begin{array}{c}\text { Alaska } \\
\text { Fisheries } \\
\text { Science } \\
\text { Center - } \\
\text { NOAA/N } \\
\text { MFS } \\
\text { (Seattle } \\
\text { WA, } \\
\text { USA) }\end{array}$} & \multirow{3}{*}{10} & \multirow{3}{*}{67} & \multirow{3}{*}{$c y t b$} & \multirow{3}{*}{3} & $\begin{array}{l}\text { LN90 } \\
8942\end{array}$ & $\begin{array}{c}100 \% \mathrm{G} \\
\text { macrocep } \\
\text { halus }\end{array}$ & \multirow{3}{*}{ - } \\
\hline & & & & & & & & $\begin{array}{l}\text { LN90 } \\
8943\end{array}$ & $\begin{array}{c}100 \% \mathrm{G} \\
\text { macrocep } \\
\text { halus }\end{array}$ & \\
\hline & & & & & & & & $\begin{array}{l}\text { LN90 } \\
8941\end{array}$ & $\begin{array}{c}100 \% \text { G. } \\
\text { macrocep } \\
\text { halus }\end{array}$ & \\
\hline & & \multirow{3}{*}{$\begin{array}{l}\text { Gadus } \\
\text { morhua }\end{array}$} & \multirow{3}{*}{ Fishlab } & \multirow{3}{*}{3} & \multirow{3}{*}{27} & \multirow{3}{*}{$c y t b$} & \multirow{3}{*}{3} & $\begin{array}{l}\text { LN90 } \\
8938\end{array}$ & $\begin{array}{l}100 \% \text { G. } \\
\text { morhua }\end{array}$ & \multirow{3}{*}{ - } \\
\hline & & & & & & & & $\begin{array}{l}\text { LN90 } \\
8939\end{array}$ & $\begin{array}{c}100 \% \text { G. } \\
\text { morhua }\end{array}$ & \\
\hline & & & & & & & & $\begin{array}{c}\text { LN90 } \\
8940\end{array}$ & $\begin{array}{c}100 \% \text { G. } \\
\text { morhua }\end{array}$ & \\
\hline & & \multirow[b]{3}{*}{$\begin{array}{l}\text { Gadus } \\
\text { ogac }\end{array}$} & \multirow{2}{*}{$\begin{array}{c}\text { Fisheries } \\
\text { and } \\
\text { Oceans, } \\
\text { Maurice } \\
\text { Lamonta } \\
\text { gne } \\
\text { Institute } \\
\text { (Mont- } \\
\text { Joli Qc, } \\
\text { Canada) } \\
\end{array}$} & \multirow[b]{2}{*}{5} & \multirow[b]{2}{*}{21} & \multirow[b]{3}{*}{$c y t b$} & \multirow[b]{2}{*}{2} & $\begin{array}{l}\text { LN90 } \\
8944\end{array}$ & $\begin{array}{c}100 \% \\
\text { G.ogac }\end{array}$ & \\
\hline & & & & & & & & $\begin{array}{l}\text { LN90 } \\
8945\end{array}$ & $\begin{array}{c}100 \% \\
\text { G.ogac }\end{array}$ & - \\
\hline & & & $\begin{array}{c}\text { Departa } \\
\text { mento de } \\
\text { Bioquími } \\
\text { ca de } \\
\text { Alimento } \\
\text { s, } \\
\text { Instituto } \\
\text { de } \\
\text { Investiga } \\
\text { ciones } \\
\text { Marinas } \\
\text { CSIC } \\
\text { (Vigo, } \\
\text { Spain) } \\
\end{array}$ & 1 & 21 & & - & & & \\
\hline & & Melanogr & Fishlab & 5 & 21 & $c y t b$ & & & & \\
\hline
\end{tabular}




\begin{tabular}{|c|c|c|c|c|c|c|c|c|c|c|}
\hline & & $\begin{array}{c}\text { ammus } \\
\text { aeglefinus }\end{array}$ & & & & & & & & \\
\hline & & $\begin{array}{c}\text { Merlangiu } \\
s \\
\text { merlangus }\end{array}$ & Fishlab & 5 & 21 & cytb & & & & \\
\hline & & $\begin{array}{c}\text { Microgad } \\
\text { us } \\
\text { proximus }\end{array}$ & $\begin{array}{c}\text { Alaska } \\
\text { Fisheries } \\
\text { Science } \\
\text { Center - } \\
\text { NOAA/N } \\
\text { MFS } \\
\text { (Seattle } \\
\text { WA, } \\
\text { USA) } \\
\end{array}$ & 5 & 67 & cytb & & & & \\
\hline & & $\begin{array}{c}\text { Micromes } \\
\text { istius } \\
\text { poutassou }\end{array}$ & Fishlab & 5 & 21 & cytb & & & & \\
\hline & & $\begin{array}{c}\text { Pollachiu } \\
\text { s virens }\end{array}$ & Fishlab & 5 & 21 & cytb & & & & \\
\hline & & $\begin{array}{l}\text { Theragra } \\
\text { chalcogra }\end{array}$ & $\begin{array}{c}\text { NOAA } \\
\text { Fisheries } \\
\text { - Alaska } \\
\text { Fisheries } \\
\text { Science } \\
\text { Center } \\
\text { (Seattle } \\
\text { WA, } \\
\text { USA) } \\
\end{array}$ & 6 & 67 & & & & & \\
\hline & & $\begin{array}{c}\text { chalcogra } \\
\text { mma }\end{array}$ & $\begin{array}{c}\text { Alaska } \\
\text { Fisheries } \\
\text { Science } \\
\text { Center - } \\
\text { NOAA/N } \\
\text { MFS } \\
\text { (Seattle } \\
\text { WA, } \\
\text { USA) }\end{array}$ & 5 & 67 & cytb & & & & \\
\hline \multirow{6}{*}{$\begin{array}{l}\text { Perciforme } \\
\text { s }\end{array}$} & \multirow{6}{*}{$\begin{array}{c}\text { Gempylida } \\
\text { e }\end{array}$} & \multirow{6}{*}{$\begin{array}{l}\text { Lepidocyb } \\
\text { ium } \\
\text { flavobrun } \\
\text { neum }\end{array}$} & \multirow{2}{*}{\begin{tabular}{|c|} 
NOAA \\
Fisheries, \\
Pacific \\
Islands \\
Fisheries \\
Science \\
Center \\
(Honolul \\
u H,I \\
USA) \\
\end{tabular}} & \multirow[b]{2}{*}{2} & \multirow[b]{2}{*}{77} & \multirow{6}{*}{ COI } & \multirow[b]{2}{*}{2} & $\begin{array}{l}\text { LN90 } \\
7515\end{array}$ & $\begin{array}{c}100 \% \\
\text { L.flavobru } \\
\text { nneum }\end{array}$ & $\begin{array}{c}100 \% \\
\text { L.flavobru } \\
\text { nneum }\end{array}$ \\
\hline & & & & & & & & $\begin{array}{r}\text { LN90 } \\
7516\end{array}$ & $\begin{array}{c}100 \% \\
\text { L.flavobru } \\
\text { nneum }\end{array}$ & $\begin{array}{c}100 \% \\
\text { L.flavobru } \\
\text { nneum }\end{array}$ \\
\hline & & & \multirow{2}{*}{$\begin{array}{c}\text { Australia } \\
n \\
\text { museum }\end{array}$} & \multirow{2}{*}{2} & \multirow{2}{*}{57} & & \multirow{2}{*}{2} & $\begin{array}{l}\text { LN90 } \\
7517\end{array}$ & $\begin{array}{c}100 \% \\
\text { L.flavobru } \\
\text { nneum }\end{array}$ & $\begin{array}{c}100 \% \\
\text { L.flavobru } \\
\text { nneum }\end{array}$ \\
\hline & & & & & & & & $\begin{array}{l}\text { LN90 } \\
7518\end{array}$ & $\begin{array}{c}100 \% \\
\text { L.flavobru } \\
\text { nneum }\end{array}$ & $\begin{array}{c}100 \% \\
\text { L.flavobru } \\
\text { nneum }\end{array}$ \\
\hline & & & \multirow{2}{*}{$\begin{array}{c}\text { Biodivers } \\
\text { ity } \\
\text { Research } \\
\text { Center, } \\
\text { Academi } \\
\text { a Sinica } \\
\text { (Taipei, } \\
\text { Taiwan) }\end{array}$} & \multirow[b]{2}{*}{2} & \multirow[b]{2}{*}{-} & & \multirow[b]{2}{*}{2} & $\begin{array}{l}\text { LN90 } \\
7519\end{array}$ & $\begin{array}{c}100 \% \\
\text { L.flavobru } \\
\text { nneum }\end{array}$ & $\begin{array}{c}100 \% \\
\text { L.flavobru } \\
\text { nneum } \\
\end{array}$ \\
\hline & & & & & & & & $\begin{array}{l}\text { LN90 } \\
7520\end{array}$ & $\begin{array}{c}100 \% \\
\text { L.flavobru } \\
\text { nneum }\end{array}$ & $\begin{array}{c}100 \% \\
\text { L.flavobru } \\
\text { nneum }\end{array}$ \\
\hline
\end{tabular}




\begin{tabular}{|c|c|c|c|c|c|c|c|c|c|}
\hline & $\begin{array}{c}\text { Rexea } \\
\text { promethe } \\
\text { oides }\end{array}$ & $\begin{array}{c}\text { Biodivers } \\
\text { ity } \\
\text { Research } \\
\text { Center, } \\
\text { Academi } \\
\text { a Sinica } \\
\text { (Taipei, } \\
\text { Taiwan) } \\
\end{array}$ & 1 & - & $C O I$ & 1 & $\begin{array}{l}\text { LN90 } \\
8934\end{array}$ & $\begin{array}{c}100 \% \\
\text { Rexea } \\
\text { spp. }\end{array}$ & $\begin{array}{c}100 \% R . \\
\text { prometheo } \\
\text { ides }\end{array}$ \\
\hline & \multirow{5}{*}{$\begin{array}{l}\text { Rexea } \\
\text { solandri }\end{array}$} & \multirow{5}{*}{$\begin{array}{c}\text { School of } \\
\text { Biomedic } \\
\text { al } \\
\text { Sciences, } \\
\text { Universit } \\
\text { y of } \\
\text { Queensla } \\
\text { nd (St } \\
\text { Lucia } \\
\text { QLD, } \\
\text { Australia } \\
\text { ) } \\
\end{array}$} & \multirow{5}{*}{5} & \multirow{5}{*}{57} & \multirow{5}{*}{$C O I$} & \multirow{5}{*}{5} & $\begin{array}{l}\text { LN90 } \\
7526 \\
\end{array}$ & $\begin{array}{c}100 \% \\
\text { R.solandri }\end{array}$ & $\begin{array}{c}100 \% \\
\text { R.solandri }\end{array}$ \\
\hline & & & & & & & $\begin{array}{l}\text { LN90 } \\
7527\end{array}$ & $\begin{array}{c}100 \% \\
\text { R.solandri }\end{array}$ & $\begin{array}{c}100 \% \\
\text { R.solandri }\end{array}$ \\
\hline & & & & & & & $\begin{array}{l}\text { LN90 } \\
7528 \\
\end{array}$ & $\begin{array}{c}100 \% \\
\text { R.solandri }\end{array}$ & $\begin{array}{c}100 \% \\
\text { R.solandri }\end{array}$ \\
\hline & & & & & & & $\begin{array}{l}\text { LN90 } \\
7529\end{array}$ & $\begin{array}{c}100 \% \\
\text { R.solandri }\end{array}$ & $\begin{array}{c}100 \% \\
\text { R.solandri }\end{array}$ \\
\hline & & & & & & & $\begin{array}{l}\text { LN90 } \\
7530\end{array}$ & $\begin{array}{c}100 \% \\
\text { R.solandri }\end{array}$ & $\begin{array}{c}100 \% \\
\text { R.solandri }\end{array}$ \\
\hline & \multirow{5}{*}{$\begin{array}{l}\text { Ruvettus } \\
\text { pretiosus }\end{array}$} & $\begin{array}{c}\text { Australia } \\
\mathrm{n} \\
\text { Museum }\end{array}$ & 1 & 57 & \multirow{5}{*}{$\mathrm{COI}$} & 1 & $\begin{array}{l}\text { LN90 } \\
7521\end{array}$ & $\begin{array}{c}100 \% \\
\text { R.pretiosu } \\
\text { s }\end{array}$ & $\begin{array}{c}100 \% \\
\text { R.pretiosu } \\
\text { s }\end{array}$ \\
\hline & & $\begin{array}{l}\text { Biodivers } \\
\text { ity } \\
\text { Research }\end{array}$ & \multirow{4}{*}{4} & \multirow[b]{4}{*}{37} & & \multirow{4}{*}{2} & $\begin{array}{l}\text { LN90 } \\
7522\end{array}$ & $\begin{array}{c}100 \% \\
\text { R.pretiosu } \\
\text { s }\end{array}$ & $\begin{array}{c}100 \% \\
\text { R.pretiosu } \\
\text { s }\end{array}$ \\
\hline & & $\begin{array}{l}\text { Center, } \\
\text { Academi } \\
\text { a Sinica }\end{array}$ & & & & & $\begin{array}{l}\text { LN90 } \\
7523\end{array}$ & $\begin{array}{c}100 \% \\
\text { R.pretiosu } \\
s\end{array}$ & $\begin{array}{c}100 \% \\
\text { R.pretiosu } \\
s\end{array}$ \\
\hline & & $\begin{array}{c}\text { (Taipei, } \\
\text { Taiwan) } \\
\text { Local }\end{array}$ & & & & & $\begin{array}{l}\text { LN90 } \\
7524\end{array}$ & $\begin{array}{c}100 \% \\
\text { R.pretiosu } \\
s \\
\end{array}$ & $\begin{array}{c}100 \% \\
\text { R.pretiosu } \\
s \\
\end{array}$ \\
\hline & & $\begin{array}{l}\text { Health } \\
\text { Authority } \\
\text { of Milan } \\
\text { (Milan, } \\
\text { Italy) }\end{array}$ & & & & & $\begin{array}{l}\text { LN90 } \\
7525\end{array}$ & $\begin{array}{c}100 \% \\
\text { R.pretiosu } \\
s\end{array}$ & $\begin{array}{c}100 \% \\
\text { R.pretiosu } \\
s\end{array}$ \\
\hline & $\begin{array}{c}\text { Thyrsites } \\
\text { atun }\end{array}$ & $\begin{array}{c}\text { Departm } \\
\text { ent of } \\
\text { Chemistr } \\
\text { y, } \\
\text { Tshwane } \\
\text { Universit } \\
\text { y of } \\
\text { Technolo } \\
\text { gy } \\
\text { (Pretoria, } \\
\text { South } \\
\text { Africa) }\end{array}$ & 1 & 81 & $C O I$ & - & & & \\
\hline Moronidae & $\begin{array}{c}\text { Dicentrar } \\
\text { chus } \\
\text { labrax }\end{array}$ & FishLab & 10 & 34 & $\mathrm{COI}$ & & & & \\
\hline $\begin{array}{c}\text { Notothenii } \\
\text { dae }\end{array}$ & $\begin{array}{c}\text { Dissostich } \\
\text { us } \\
\text { eleginoide } \\
\text { s }\end{array}$ & FishLab & 5 & 21 & $C O I$ & & & & \\
\hline $\begin{array}{c}\text { Scombrida } \\
\text { e }\end{array}$ & $\begin{array}{c}\text { Allothunn } \\
\text { us fallai }\end{array}$ & $\begin{array}{c}\text { Marine } \\
\text { Vertebrat } \\
\text { e } \\
\text { Collectio } \\
\text { n Scripps } \\
\end{array}$ & 1 & - & $C O I$ & - & & & \\
\hline
\end{tabular}




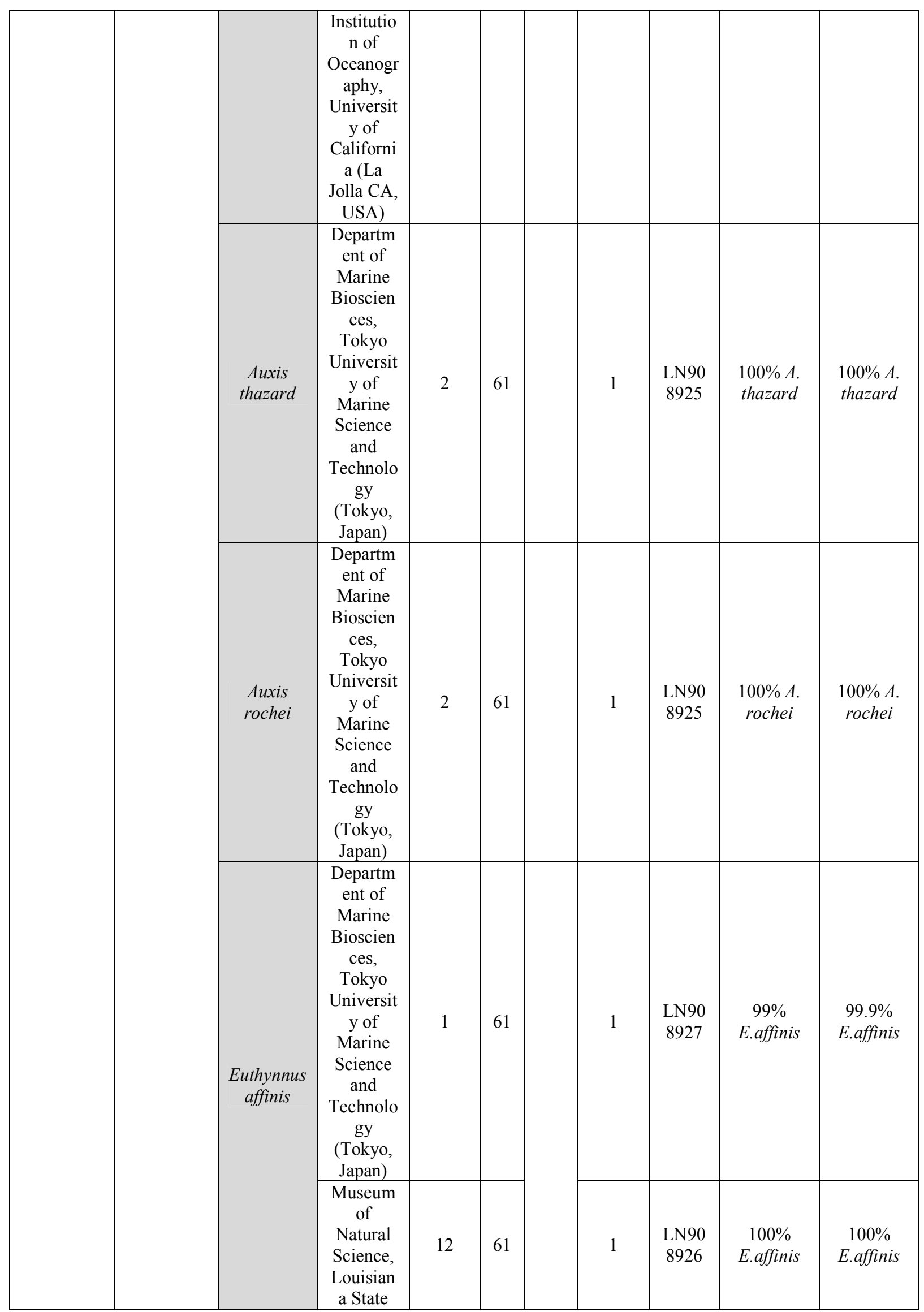




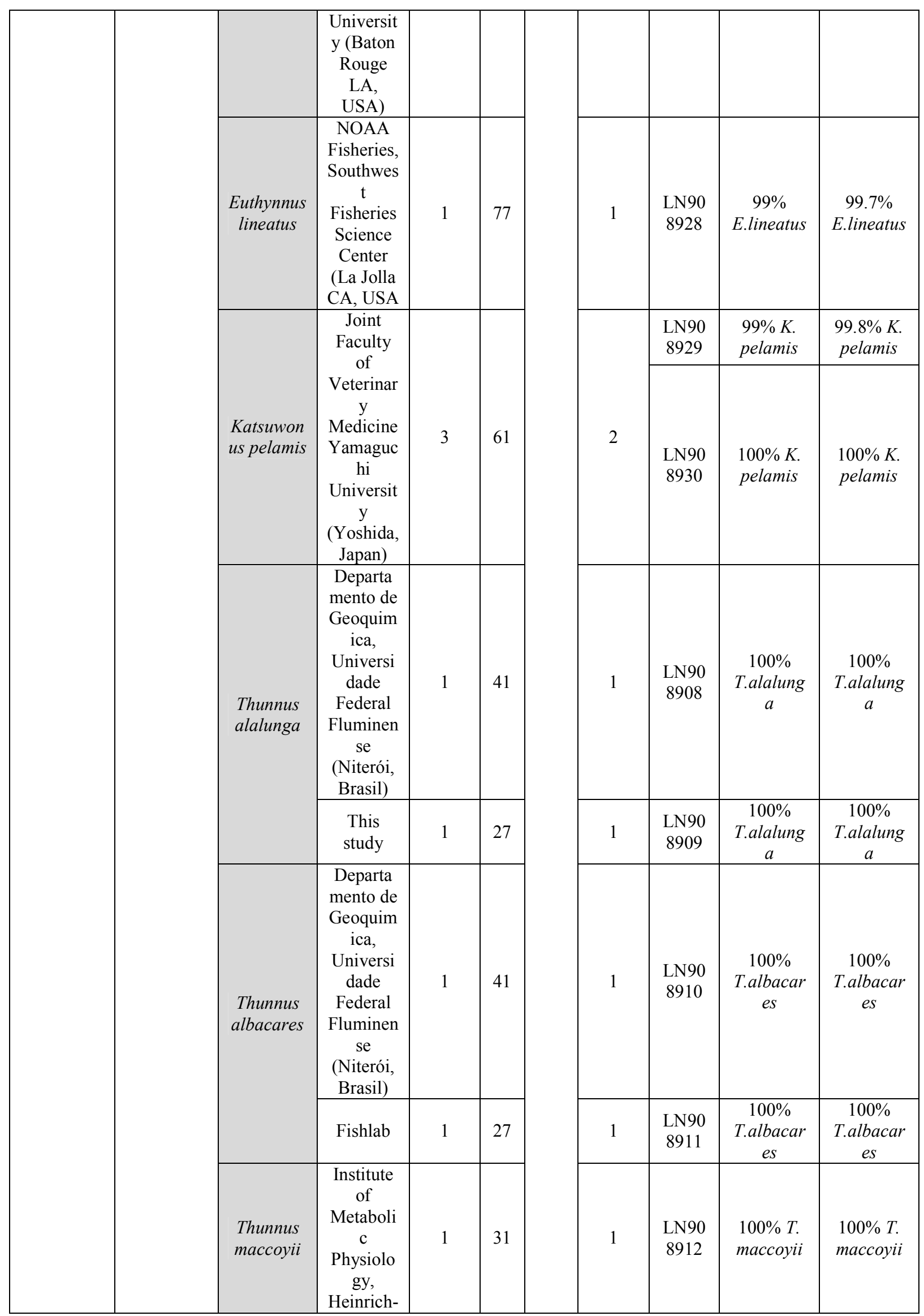




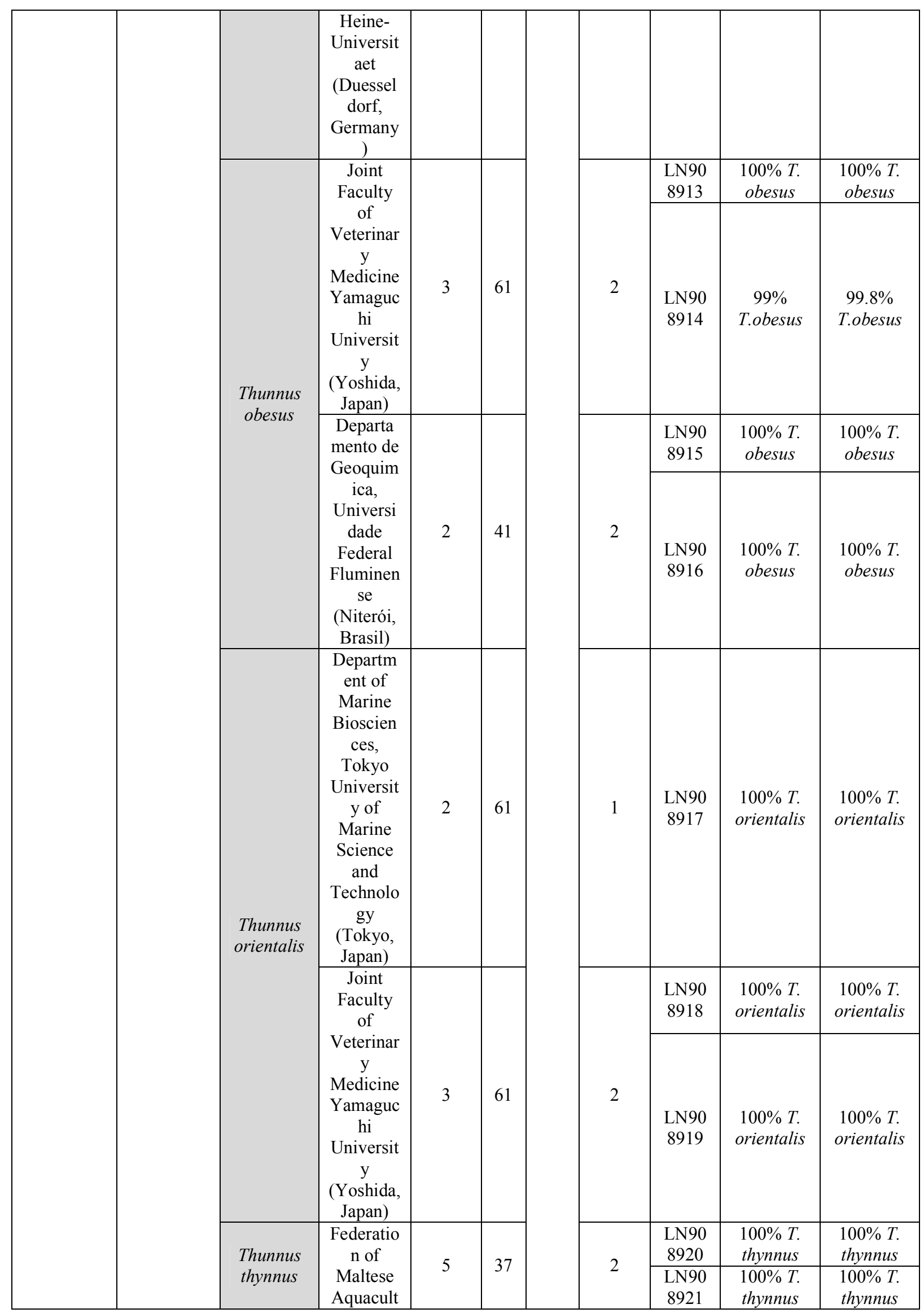




\begin{tabular}{|c|c|c|c|c|c|c|c|c|c|c|}
\hline & & & $\begin{array}{c}\text { ure } \\
\text { Producer } \\
\text { s } \\
\text { (Valletta, } \\
\text { Malta) }\end{array}$ & & & & & & & \\
\hline & & & $\begin{array}{l}\text { Departm } \\
\text { ent of } \\
\text { Marine }\end{array}$ & & & & & $\begin{array}{l}\text { LN90 } \\
8922\end{array}$ & $\begin{array}{l}100 \% \mathrm{~T} \text {. } \\
\text { tonggol }\end{array}$ & $\begin{array}{l}100 \% \mathrm{~T} . \\
\text { tonggol }\end{array}$ \\
\hline & & & $\begin{array}{c}\text { Bioscien } \\
\text { ces, }\end{array}$ & & & & & $\begin{array}{l}\text { LN90 } \\
8923\end{array}$ & $\begin{array}{l}100 \% \mathrm{~T} . \\
\text { tonggol }\end{array}$ & $\begin{array}{l}100 \% \mathrm{~T} . \\
\text { tonggol }\end{array}$ \\
\hline & & $\begin{array}{c}\text { Thunnus } \\
\text { tonggol }\end{array}$ & $\begin{array}{c}\text { Tokyo } \\
\text { Universit } \\
\text { y of } \\
\text { Marine } \\
\text { Science } \\
\text { and } \\
\text { Technolo } \\
\text { gy } \\
\text { (Tokyo, } \\
\text { Japan) } \\
\end{array}$ & 10 & 61 & & 3 & $\begin{array}{l}\text { LN90 } \\
8924\end{array}$ & $\begin{array}{l}100 \% \mathrm{~T} \text {. } \\
\text { tonggol }\end{array}$ & $\begin{array}{l}100 \% T \\
\text {.tonggol }\end{array}$ \\
\hline & & $\begin{array}{c}\text { Scomber } \\
\text { scombrus }\end{array}$ & FishLab & 5 & 27 & & & & & \\
\hline & Sparidae & $\begin{array}{l}\text { Sparus } \\
\text { aurata }\end{array}$ & FishLab & 10 & 27 & & & & & \\
\hline & Xiphiidae & $\begin{array}{l}\text { Xiphias } \\
\text { gladius }\end{array}$ & FishLab & 5 & 21 & & & & & \\
\hline Pleuronecti & $\begin{array}{c}\text { Pleuronect } \\
\text { idae }\end{array}$ & $\begin{array}{l}\text { Atheresth } \\
\text { es stomias }\end{array}$ & FishLab & 10 & 71 & & & & & \\
\hline formes & Soleidae & $\begin{array}{l}\text { Solea } \\
\text { solea }\end{array}$ & FishLab & 10 & 27 & & & & & \\
\hline & & & $\begin{array}{c}\text { Universit } \\
\mathrm{y} \text { of }\end{array}$ & & & & & $\begin{array}{l}\text { LN90 } \\
8931\end{array}$ & $\begin{array}{l}100 \% \mathrm{~A} . \\
\text { fimbria }\end{array}$ & $\begin{array}{l}100 \% A \text {. } \\
\text { fimbria }\end{array}$ \\
\hline Scorpaenif & Anoplopo & Anoplopo & $\begin{array}{l}\text { Washingt } \\
\text { on Fish }\end{array}$ & 5 & 77 & $C O I$ & 3 & $\begin{array}{l}\text { LN90 } \\
8932\end{array}$ & $\begin{array}{l}100 \% A . \\
\text { fimbria }\end{array}$ & $\begin{array}{l}100 \% A \\
\text { fimbria }\end{array}$ \\
\hline ormes & matidae & fimbria & $\begin{array}{c}\text { Collectio } \\
\text { n (Seattle } \\
\text { WA, } \\
\text { USA) }\end{array}$ & & & & & $\begin{array}{l}\text { LN90 } \\
8933\end{array}$ & $\begin{array}{c}100 \% A \\
\text { fimbria }\end{array}$ & $\begin{array}{l}100 \% A . \\
\text { fimbria }\end{array}$ \\
\hline
\end{tabular}

646

647 648

649

650
Table 1. Tissue samples collected in this study; dark gray boxes: target species; light gray boxes: non-target species; white boxes: species used in the preparation of sushi. 


\begin{tabular}{|c|c|c|c|c|c|c|}
\hline Primer & Sequence (5'-3') & Target species & $\begin{array}{c}\text { Lenght } \\
\text { (bp) }\end{array}$ & Position & $\begin{array}{c}\text { AL } \\
\text { (bp) }\end{array}$ & $\begin{array}{l}\text { MT } \\
\left({ }^{\circ} \mathrm{C}\right)\end{array}$ \\
\hline For-COI & TATCTHGTATTYGGTGC & All the target species & 17 & 5 & - & 47.5 \\
\hline $\begin{array}{l}\text { Gem- } \\
\text { COIR }\end{array}$ & TGGGAGATGGCTGCG & $\begin{array}{l}\text { R. pretiosus; } L \text {. } \\
\text { flavobrunneum }\end{array}$ & 15 & 483 & 479 & 53.3 \\
\hline $\begin{array}{l}\text { Sable- } \\
\text { COIR. } 1\end{array}$ & CAAGAGGGCGCCAG & \multirow{2}{*}{ A.fimbria } & 14 & 144 & 139 & 48.0 \\
\hline $\begin{array}{c}\text { Sable- } \\
\text { COIR. } 2\end{array}$ & CAAGTTACTGGCGAG & & 15 & 408 & 403 & 47.8 \\
\hline $\begin{array}{l}\text { Tunas- } \\
\text { COIR }\end{array}$ & AGAAGCTAGGAGHAGAA & $\begin{array}{c}\text { Thunnus spp.; } \\
\text { Allothunnus spp; Auxis } \\
\text { spp.; Euthynnus spp.; } \\
\text { Katsuwonus spp. }\end{array}$ & 17 & 294 & 291 & 48.7 \\
\hline $\begin{array}{l}\text { Cod- } \\
\text { cytbF }\end{array}$ & CTAGGTGGCGTACTTG & \multirow{4}{*}{ Gadus spp. } & 16 & \multirow{3}{*}{$861 / 862$} & \multirow{4}{*}{193} & 51.7 \\
\hline $\begin{array}{l}\text { Cod- } \\
\text { cytbF.1 }\end{array}$ & CTAGGTGGCGTGCTTG & & 16 & & & 54.3 \\
\hline $\begin{array}{c}\text { Cod- } \\
\text { cytbF.2 }\end{array}$ & TAGGTGGCGTGCTTG & & 15 & & & 50.6 \\
\hline $\begin{array}{l}\text { Cod- } \\
\text { cytbR }\end{array}$ & GTCCGATGATAATGAAGG & & 18 & 1054 & & 51.4 \\
\hline 16Sfor. 1 & TTRACCGTGCGAAGG & \multirow{6}{*}{$\begin{array}{c}\text { All the species included } \\
\text { in the study }\end{array}$} & 15 & 1010 & \multirow{2}{*}{60} & 49.2 \\
\hline 16Srev.1 & TGCCWTTCATACMGGTC & & 17 & 1069 & & 51.6 \\
\hline 16Sfor. 2 & GTACCTTTTGCATCATGA & & 18 & 210 & \multirow{2}{*}{90} & 49.1 \\
\hline 16Srev.2 & TGTCTTGGAGTAGCTC & & 16 & 299 & & 49.2 \\
\hline 16Sfor. 3 & TACGACCTCGATGTTG & & 16 & 1437 & \multirow{2}{*}{115} & 49.2 \\
\hline 16Srev.3 & TGACCTGGATTACTCC & & 16 & 1551 & & 49.2 \\
\hline
\end{tabular}

651

652

653

654

Table 2. Primer designed for the multiplex PCR. Highlighted in grey: primers finally selected. bp: base pair; AL: Amplicon length; MT: Melting Temperature. 


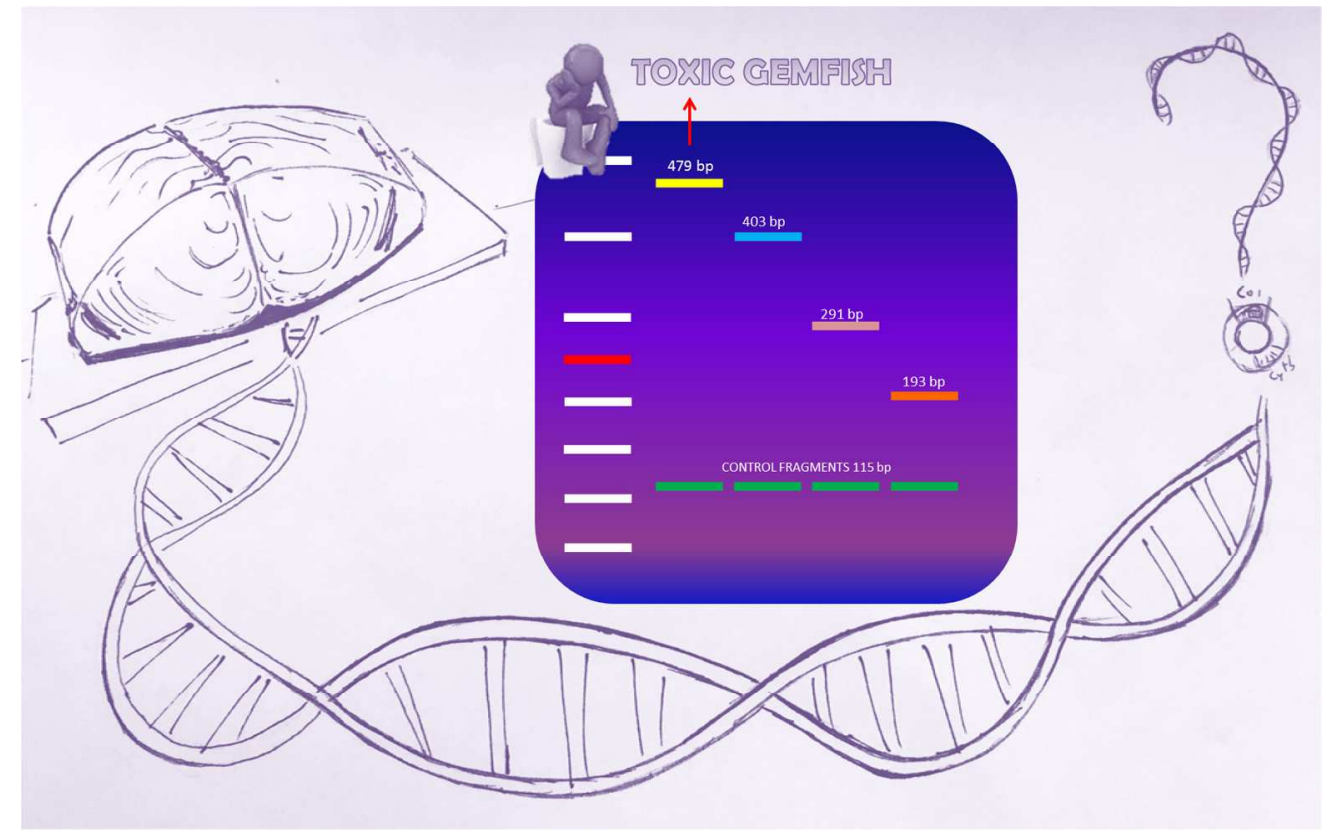

TOC graphic

$150 \times 95 \mathrm{~mm}(300 \times 300 \mathrm{DPI})$ 


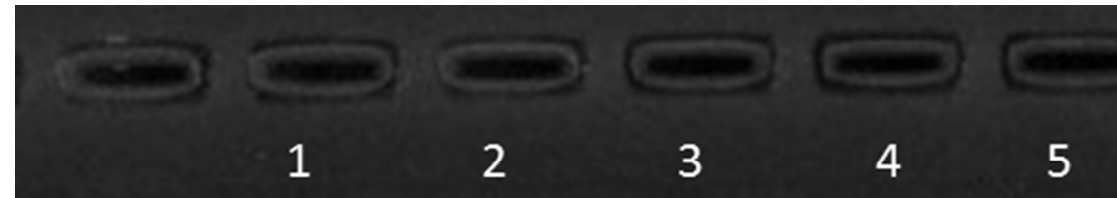

\section{0 bp}

$250 \mathrm{bp}$

200 bp

$150 \mathrm{bp}$

$100 \mathrm{bp}$

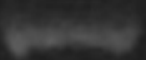

\section{5}

(150

.

50 bp

Electrophoresis on agarose gel (4\%) of the species selected as target after the Multiplex PCR; the "genus control" band of 115 bp is clearly visible together with the species-specific band. Line 1, Lepidocybium flavobrunneum (479 bp), bp); line 2, Anoplopoma fimbria (403 bp); line 3, Thunnus albacares (291 bp); line 4, Gadus morhua (193 bp); line 5, H2O; lines 1,2,3,4: 16S rRNA positive control bands (115 bp). DNA ladder band size: 1000 bp, 900 bp, 800 bp, 700 bp, 600 bp, 500 bp, 400 bp, 300 bp, 250 bp, 200 bp, 150 bp, 100 bp, 50 bp. $46 \times 63 \mathrm{~mm}(300 \times 300 \mathrm{DPI})$ 